\title{
Ummessaolokauden energiansaannin vaikutus lypsylehmien aineen- vaihdunnan säätelyyn, syöntiin ja maitotuotokseen
}

\author{
Siru Salin ${ }^{1)}$, Kari Elo ${ }^{1)}$, Pirjo Pursiainen ${ }^{1)}$, Juhani Taponen ${ }^{2)}$, Aila Vanhatalo ${ }^{1)}$, Tuomo Kokkonen ${ }^{1)}$ \\ 1)Maataloustieteiden laitos, PL 28, 00014 Helsingin yliopisto \\ 2) Kliinisen tuotantoeläinlääketieteen osasto, Paroninkuja 20, 04920 Saarentaus \\ etunimi.sukunimi@helsinki.fi
}

\section{Tiivistelmä}

Poikimisen läheisyydessä lehmän on sopeuduttava nopeasti lisääntyvän maidontuotannon aiheuttamiin tarpeisiin mobilisoimalla rasvaa, valkuaista ja kivennäisaineita kudoksistaan. Tiineyden lopulla ääreiskudoksiin kehittyvän insuliiniresistenssin avulla glukoosi ohjautuu sikiön ja utareen käyttöön. Liialliseen ummessaolokauden ruokintaan liittyy aiempien tutkimusten mukaan voimakas syönnin väheneminen poikimisen lähestyessä. Poikimisen aikainen lihavuus voi vaimentaa insuliinin vaikutusta kudoksissa ja voimistaa rasvakudosten käyttöä energianlähteenä tuotoskauden alussa. Tämä heikentää lehmän syöntikykyä ja altistaa eläimen aineenvaihduntasairauksille.

Tutkimuksessa selvitettiin, miten ummessaolokauden vapaa (V) tai rajoitettu (R) ruokinta vaikuttaa lehmien kuntoluokan ja elopainon kehittymiseen. Ruokinnan vaikutusta rasvakudosmobilisaatioon ja aineenvaihdunnan säätelyyn tutkittiin glukoosirasituskokein tiineyden lopussa (-7 pv) ja tuotoskauden alussa $(+10 \mathrm{pv})$. Lisäksi tutkittiin, miten energiansaanti vaikuttaa lehmien syöntiin ja maitotuotokseen poikimisen jälkeen.

Kokeessa oli 16 vähintään toista kertaa poikivaa ay-lehmää. V-ryhmä sai viikoilla 6-4 ennen poikimista säilörehua $142 \%$ (141 MJ ME/pv) ja R-ryhmä $100 \%$ (99 MJ ME/pv) energiantarpeesta. Tunnutusruokinnan alkaessa (3 vk ennen poikimista) V-ryhmän energiansaantia alettiin rajoittaa asteittain R-ryhmän tasolle odotettuun poikimapäivään mennessä. Tunnutusruokintana ryhmät saivat väkirehua $30 \% \mathrm{ME}$ :stä. Poikimisen jälkeen ryhmät saivat vapaasti säilörehua, väkirehuannos nostettiin asteittain $16 \mathrm{~kg} / \mathrm{pv}$.

V-ryhmä söi säilörehua viikoilla 6 -4 ennen poikimista $12,6 \mathrm{~kg} \mathrm{ka} / \mathrm{pv}$ ja R-ryhmä $8,8 \mathrm{~kg} \mathrm{ka} / \mathrm{pv}$. Poikimisen jälkeen kuiva-aineen syönnissä ei ollut eroja. R-ryhmän vasikat olivat painavampia kuin V-ryhmän (47,0 vs. $40,7 \mathrm{~kg}, \mathrm{p}=0,08)$, elopainon lisäys V-ryhmässä oli odotettua pienempi ennen poikimista. R-ryhmän maitotuotos oli suurempi $(44,3$ vs. 40,5 kg/pv, p=0,05) ja V-ryhmän EKM-tuotos oli viikoilla 4 ja 6 pienempi kuin R-ryhmän.

V-ryhmän plasman NEFA-pitoisuus oli ennen poikimista pienempi ja insuliinipitoisuus suurempi $(p=0,09)$ kuin R-ryhmän. Glukoosirasituskokeissa ei havaittu muutoksia insuliiniherkkyyttä kuvaavissa glukoosiparametreissa. NEFA-pitoisuuden muutos rasituskokeen aikana viittaa siihen, että rasvakudoksen insuliiniherkkyys oli mahdollisesti suurempi R-ryhmällä ennen poikimista ja Vryhmällä poikimisen jälkeen.

Ummessaolokauden runsas energiansaanti ei aiheuttanut merkittäviä muutoksia lehmien aineenvaihdunnan säätelyssä ja kudosmobilisaatiossa tai elopainossa ja kuntoluokan muutoksissa poikimisen läheisyydessä rajoitettuun ruokintaan verrattuna. Ummessaoloaikana rajoitetusti ruokittujen lehmien maitotuotos oli suurempi laktaatiokauden alussa.

Asiasanat: aineenvaihdunnan säätely, insuliiniresistenssi, kudosmobilisaatio 


\section{Johdanto}

Poikimisen läheisyydessä lehmän on sopeuduttava nopeasti lisääntyvän maidontuotannon aiheuttamiin tarpeisiin mobilisoimalla rasvaa, valkuaista ja kivennäisaineita kudoksistaan. Poikimisen läheisyydessä veren insuliinipitoisuuden väheneminen ja lihas- sekä rasvakudoksen insuliinivasteen heikkeneminen edistävät ravintoaineiden kulkeutumista sikiön ja utareen käyttöön (Bell 1995). Liian suuri energiansaanti tai runsas väkirehun osuus ummessaolokauden ruokinnassa lisää veren insuliinipitoisuutta huomattavasti (Kokkonen ym. 2004, Kokkonen ym. 2005), mikä voimistaa kudosten insuliiniresistenssiä (Holtenius ym. 2003). Tällöin tämä normaali, poikimisen läheisyyteen ajoittuva, sopeutumismekanismi toimii ylikorostuneesti ja rasvakudosmobilisaatio lisääntyy. Insuliiniresistenssin kehittymiseen liittyy kohonnut veren vapaiden rasvahappojen (NEFA) pitoisuus, mikä lisää rasvan kertymistä lihaksiin ja maksaan. Rasvan kertyminen kudoksiin ja kohonnut veren vapaiden rasvahappojen pitoisuus inhiboivat insuliinin stimuloimaa glukoosin ottoa soluissa (Boden 2011). Lehmien herkkyys insuliiniresistenssille ja glukoosin siedolle vaihtelee yksilöiden sekä rotujen välillä, ja insuliiniresistenssin voimakkuus on todennäköisesti osin geneettisesti säädeltyä (Bossaert ym. 2009, Patton ym. 2009).

Liialliseen ummessaolokauden ruokintaan liittyy aiempien tutkimusten mukaan voimakas syönnin väheneminen poikimisen lähestyessä rajoitettuun ruokintaan verrattuna (Grummer ym. 2004, Dann ym. 2006, Douglas ym. 2006). Poikimisen aikainen lihavuus voi vaimentaa insuliinin vaikutusta kudoksissa ja voimistaa rasvakudosten käyttöä energianlähteenä tuotoskauden alussa (Holtenius ym. 2003). Tällöin plasman vapaiden rasvahappojen pitoisuus lisääntyy, mikä saattaa voimistaa kudosten insuliiniresistenssiä (Pires ym. 2008, Salin ym. 2010). Tämä heikentää lehmän syöntikykyä ja altistaa eläimen aineenvaihduntasairauksille.

Poikimista edeltävän syönnin heikkenemistä voidaan ehkäistä ruokkimalla ummessaolevia lehmiä rajoitetusti laskennallisen energiantarpeen mukaisesti (Kokkonen ym. 2005). Vapaalla seosrehuruokinnalla lehmän ajatellaan pystyvän itse säätämään kuiva-aineen syöntiään energia- ja ravintoainetarpeiden mukaiseksi. Tutkimukset ovat kuitenkin osoittaneet, että ummessaolevat lehmät syövät usein 50-60 \% enemmän kuin niiden laskennallinen energiantarve edellyttäisi (Loor ym. 2006).

Aiemmat tutkimustulokset ummessaolokauden ruokinnan vaikutuksista elopainon, kuntoluokan ja aineenvaihdunnan muutoksiin poikimisen läheisyydessä sekä poikimisen jälkeiseen kuiva-aineen syöntiin ja tuotokseen ovat olleet ristiriitaisia (Law ym. 2011). Tutkimuksessa selvitettiin, miten ummessaolokauden vapaa (V) tai rajoitettu (R) ruokinta vaikuttaa lehmien kuntoluokan ja elopainon kehittymiseen. Energiansaannin vaikutusta rasvakudosmobilisaatioon ja aineenvaihdunnan säätelyyn tutkittiin glukoosirasituskokein tiineyden lopussa $(-7 \mathrm{pv})$ ja tuotoskauden alussa $(+10 \mathrm{pv})$. Lisäksi tutkittiin, miten energiansaanti vaikuttaa lehmien syöntiin ja maitotuotokseen poikimisen jälkeen. Tutkimuksen hypoteesit olivat: 1) Ennen poikimista tapahtuva syönnin muutos laukaisee vapaasti ruokitussa ryhmässä intensiivisemmän rasvakudosmobilisaation poikimista edeltävällä viikolla, ja mobilisaatio jatkuu ensimmäisten tuotosviikkojen aikana voimakkaampana kuin vertailuryhmässä. 2) Ennen poikimista vapaasti ruokitussa ryhmässä lehmien insuliiniresistenssi on suurempi kuin vertailuryhmässä.

\section{Aineisto ja menetelmät}

Tutkimus tehtiin Viikin opetus- ja tutkimustilan navetassa 10.9.2009-1.4.2010. Koe-eläiminä oli 16 vähintään toista kertaa poikivaa, ummessaolevaa ay-lehmää. Kaksi lehmää, yksi kummastakin ryhmästä, poistettiin kokeesta poikimisen jälkeen koetekijöistä riippumattomista syistä. Koemalli oli täydellisesti satunnaistettu lohkokoe, jossa eläimet oli jaettiin pareihin odotetun poikimapäivän ja -kerran mukaan. Koe alkoi 6 viikkoa ennen oletettua poikimispäivää ja päättyi 8 viikkoa poikimisen jälkeen. Koekäsittelyinä oli vapaa tai rajoitettu säilörehuruokinta. V-ryhmä sai viikoilla 6-4 ennen poikimista säilörehua $150 \%$ ja R-ryhmä $100 \%$ energiantarpeesta. Tunnutusruokinnan alkaessa, 3 viikkoa ennen poikimista, V-ryhmän energiansaantia alettiin rajoittaa asteittain R-ryhmän tasolle odotettuun poikimapäivään mennessä. Tunnutusruokintana ryhmät saivat täysväkirehua (Krono III, Suomen Rehu Oy) 30 \% ME:stä. Poikimisen jälkeen molemmat ryhmät saivat vapaasti säilörehua, täysväkirehun (Krono III) ja puolitiivisteen (Multi-Krono Top, Suomen Rehu Oy) määrä nostettiin $16 \mathrm{~kg}$ :aan/pv asteittain 32. poikimisen jälkeiseen päivään mennessä. Kivennäistä (Tunnumelli/Pihattomelli, Rehuraisio Oy) annettiin erikseen $200 \mathrm{~g} / \mathrm{pv}$. Eläimet punnittiin ennen kokeen alkua, 2 viikon välein ja 5 pv ennen poikimista. Poikimisen jälkeen punnitukset tehtiin $1,2,6$ ja 7 ja 15 päivää sekä 4,6 ja 8 viikkoa poikimisesta. Kuntoluokitus tehtiin ennen poikimista samoina ajankohtina kuin punnitus, poikimisen jälkeen 
kuntoluokitus tehtiin 1 päivä sekä 1, 2, 4, 6 ja 8 viikkoa poikimisesta. Maitotuotos mitattiin lypsykerroittain. Maitonäytteet otettiin 1, 2, 4 ja 6 viikkoa poikimisesta. Näytteistä määritettiin rasva-, valkuais- ja laktoosipitoisuudet. Kunkin lehmän keskimääräinen viikottainen energiakorjattu maitotuotos sekä rasva-, valkuais- ja laktoosituotos on laskettu käyttäen viikon keskimääräistä maitotuotosta ja ko. viikolla määritettyä maidon koostumusta. Verinäytteitä otettiin häntäsuonesta $6,4,3$ ja 2 viikkoa sekä $8,5,3$ ja 1 päivää ennen odotettua poikimista. Näytteet otettiin myös $1,3,5$ ja 7 ja 15 päivää sekä 3,4 ja 6 viikkoa poikimisen jälkeen.

Glukoosirasituskokeita varten lehmille asetettiin katetrit molempiin kaulalaskimoihin. Glukoosirasituskoe tehtiin $7(+/-1)$ päivää ennen odotettua poikimista ja $10(+/-1)$ päivää poikimisen jälkeen klo 8.30 alkaen infusoimalla katetrin kautta suoneen glukoosia $0,25 \mathrm{~g} /$ elopainokilo (Glucos. B. Braun $300 \mathrm{mg} / \mathrm{ml}$ ) ja keräämällä verinäytteitä katetrin kautta -15, -5, 5, 10, 15, 20, 30, 40, 50, 60, 90, 120, 150 ja 180 min kuluttua infuusiosta. Lehmät olivat paastolla $1 \mathrm{~h}$ ennen kokeita sekä niiden aikana. Kaikista verinäytteistä määritettiin plasman glukoosi- ja NEFA-pitoisuudet spektrofotometrisesti, insuliinipitoisuus määritettiin ELISA-menetelmällä.

Rasituskokeiden NEFA-, glukoosi- ja insuliinipitoisuuksista laskettiin SAS-ohjelmistoon (versio 9.1) luodun makron avulla puolisuunnikasmenetelmää käyttäen lähtötason ylä- tai alapuolelle jäävän pitoisuus-aikakäyrän alainen pinta-ala (AUC, mmol/1 x 60/120/180 min). Pitoisuuksien lähtöarvoina käytettiin 15 ja 5 min ennen kokeita otettujen verinäytteiden pitoisuuksien keskiarvoa. Kokeiden aikaisten glukoosi- ja insuliinipitoisuuksien poistumisnopeuden (CR, \%/min) ja puoliintumisajan (T1/2, min) laskemiseksi pitoisuuksiin sovitettiin ensin epälineaarinen malli SAS:n NLINproseduurilla. Mallin tulosten perusteella laskettiin poistumisnopeus kaavalla: CR $=100 *(\ln [\mathrm{ta}]-$ $\ln [\mathrm{tb}]) /(\mathrm{tb}-\mathrm{ta})$, missä [ta] ja [tb] ovat pitoisuudet ajan hetkellä a ja b.

Rehunkulutus, maitotuotos, maidon pitoisuudet ja pääosa verinäytetuloksista analysoitiin toistettujen mittausten mallilla käyttäen SAS-ohjelmiston (versio 9.1) Mixed-proseduuria. Kiinteinä tekijöinä mallissa olivat ruokintakäsittely ja aika sekä niiden yhdysvaikutus, ja satunnaisena tekijänä blokki. Tulosten analysointia varten rehunkulutuksesta ja maitotuotoksesta laskettiin kullekin lehmälle viikoittaiset keskiarvot. Kunkin lehmän havaintoihin sovitettiin kolme eri kovaranssirakennetta: CS, UN ja AR(1). Kunkin muuttujan kohdalla valittiin pienimmän Bayesian Information Criterion -arvon antaneen kovarianssimallin tulokset. Maidon koostumusaineistoa ja verinäytetuloksia analysoitaessa AR(1)-kovarianssirakenteen sijasta käytettiin SP(POW)-kovarianssirakennetta, koska näytekertojen välit eivät olleet yhtä pitkät. Yksittäisten mittausten tulokset (mm. elopaino, kuntoluokka ja niiden muutokset sekä glukoosirasituskoe) analysoitiin mallilla, jossa kiinteänä tekijänä oli ruokintakäsittely ja satunnaisena tekijänä blokki. Ennen poikimista tehdyssä rasituskokeessa kiinteänä tekijänä oli lisäksi päivien lukumäärä todelliseen poikimispäivään nähden. Taulukoissa esitetyt keskiarvot ovat pienimmän neliösumman keskiarvoja.

\section{Tulokset ja tulosten tarkastelu}

V-ryhmän toteutunut ME-saanti oli viikoilla 6-4 ennen poikimista keskimäärin $42 \%$ suurempi kuin R-ryhmän (141 vs. $99 \mathrm{MJ} / \mathrm{pv}$; $\mathrm{p}<0,001)$ ja 3-1 viikkoa ennen poikimista $18 \%$ suurempi kuin Rryhmän ME-saanti (128 vs. $109 \mathrm{MJ} / \mathrm{pv}, \mathrm{p}<0,001)$. V-ryhmän säilörehun syönti oli 6-4 viikkoa ennen poikimista $12,6 \mathrm{~kg} \mathrm{ka} / \mathrm{pv} \mathrm{R}-$ ryhmän syönnin ollessa $8,8 \mathrm{~kg} / \mathrm{pv}$ ( $<<0,001$ ). Säilörehun keskimääräinen energiasisältö oli $10,7 \mathrm{MJ} / \mathrm{kg} \mathrm{ka}$. Viimeisillä kolmella poikimista edeltävillä viikoilla V-ryhmän lehmät söivät kuiva-ainetta keskimäärin $11,5 \mathrm{~kg} / \mathrm{pv}$ ja R-ryhmän lehmät $9,7 \mathrm{~kg} / \mathrm{pv}(\mathrm{p}<0,001)$.

Poikimisen jälkeen kuiva-aineen syönnissä tai ravintoaineiden saannissa ei ollut ryhmien välisiä eroja, yhtäpitävästi aiempien tutkimusten mukaan (Winkelman ym. 2008, Law ym. 2011). Ummessaolokauden ruokinta ei myöskään vaikuttanut ME-taseeseen poikimisen jälkeen; V-ryhmän ME-tase oli poikimisen jälkeen keskimäärin -48 MJ/vk ja R-ryhmän -56 MJ/vk (Taulukko 1). Toisin kuin nyt tehdyssä kokeessa, runsasenerginen ummessaolokauden ruokinta $48-25$ pv ennen poikimista vähensi kuiva-aineen syöntiä tuotoskauden alussa, lisäksi eläinten ME-tase oli negatiivisempi kuin rajoitetusti ruokituilla lehmillä 10 päivän ajan poikimisen jälkeen (Dann ym. 2006). Energiansaannin rajoittaminen tai vapaa ruokinta ennen poikimista ei vaikuttanut poikimisen jälkeiseen kuiva-aineen syöntiin, maitotuotokseen (Agenäs ym. 2003) tai energiataseeseen (Agenäs ym. 2003, Winkelman ym. 2008) eikä kuntoluokkaan (Winkelman ym. 2008) yhtäpitävästi nyt tehdyn kokeen kanssa. 
Taulukko 1. Rehujen syönti ja maitotuotos, viikot 1-8

\begin{tabular}{|c|c|c|c|c|c|}
\hline & \multirow{2}{*}{$\begin{array}{l}\text { Rajoitettu } \\
\text { ruokinta }\end{array}$} & \multirow{2}{*}{$\begin{array}{l}\text { Vapaa } \\
\text { ruokinta }\end{array}$} & \multirow[t]{2}{*}{ SEM } & \multicolumn{2}{|c|}{ Merkitsevyys } \\
\hline & & & & Ruokinta & Ruokinta*aika \\
\hline Kuiva-aineen syönti, kg/pv & 21,0 & 21,1 & 0,618 & & \\
\hline ME-tase, $\mathrm{MJ} / \mathrm{pv}$ & -56 & -48 & 7,74 & & \\
\hline Maitoa, kg/pv & 44,3 & 40,5 & 1,69 & o & o \\
\hline EKM, kg/ & 42,7 & 41,2 & 1,75 & & \\
\hline Rasvapitoisuus, $\mathrm{g} / \mathrm{kg}$ & 46,2 & 47,0 & 1,26 & & \\
\hline Valkuaispit., g/kg & 33,5 & 35,1 & 0,71 & $*$ & o \\
\hline Laktoosipit., $\mathrm{g} / \mathrm{kg}$ & 46,1 & 45,4 & 0,19 & $*$ & \\
\hline Rasvatuotos, $\mathrm{g} / \mathrm{d}$ & 1852 & 1770 & 82,3 & & $* *$ \\
\hline Valkuaistuotos, g/d & 1321 & 1334 & 60,9 & & $* * *$ \\
\hline Laktoosituotos, g/d & 1885 & 1737 & 76,6 & & $\mathrm{o}$ \\
\hline
\end{tabular}

R-ryhmän lehmien keskimääräinen maitotuotos viikoilla $1-8$ oli $3,8 \mathrm{~kg} / \mathrm{d}(\mathrm{p}=0,054)$ suurempi kuin Vryhmän lehmien (Taulukko 1). Ensimmäisten kahden laktaatioviikon aikana tuotoseroa ei ollut, mutta ero kasvoi kolmannesta laktaatioviikosta alkaen (ruokinta*aika $p=0,052$ ). V-ryhmän lehmien maidon valkuaispitoisuus oli suurempi $(\mathrm{p}<0,04)$ ja laktoosipitoisuus pienempi $(\mathrm{p}<0,02)$ kuin R-ryhmän, rasvapitoisuudessa ei ollut eroja. Rasva- ja valkuaistuotoksissa $(p<0,01)$ sekä laktoosituotoksessa $(p=0,06)$ oli yhdysvaikutus ruokinnan ja ajan välillä siten, että viikoilla 4 ja 6 V-ryhmän lehmien rasva-, valkuais- ja laktoosituotokset olivat pienemmät kuin R-ryhmän, mutta tuotoskauden alussa vastaavaa eroa ei ollut. Energiakorjatussa maitotuotoksessa (EKM) ei ollut tilastollisesti merkitsevää eroa, mikä johtuu osittain siitä, että EKM laskettiin vain viikoilta 1,2, 4 ja 6, jolloin maitonäytteitä otettiin. Toisaalta Rryhmän numeroarvoltaan $8 \mathrm{MJ} / \mathrm{pv}$ negatiivisempi ME-tase (ruokinta*aika $\mathrm{p}=0,11$ ) vastaa suuruusluokaltaan havaittua päivittäistä $1,5 \mathrm{~kg} ; \mathrm{n}$ eroa EKM-tuotoksessa.

Maitotuotoksessa ja maidon komponenttien tuotoksissa havaittu ero tuotoskauden 3. viikosta alkaen viittaa siihen, että V-ryhmän lehmillä saattoi olla puutetta ravintoaineista. Alhaisempi laktoosituotos viittaa glukoosin puutteeseen, mikä voi johtua esimerkiksi maksan liiallisesta rasvoittumisesta, jolloin maksan glukoosintuotanto (Rukkwamsuk ym. 1999, Loor ym. 2006) ja kyky hapettaa rasvahappoja (Murondoti ym. 2004) heikkenevät.

Taulukko 2. Elopainot ja kuntoluokat sekä vasikoiden syntymäpainot

\begin{tabular}{|c|c|c|c|c|}
\hline & $\begin{array}{l}\text { Rajoitettu } \\
\text { ruokinta }\end{array}$ & $\begin{array}{l}\text { Vapaa } \\
\text { ruokinta }\end{array}$ & SEM & $\begin{array}{l}\text { Merkitsevyys } \\
\text { Ruokinta }\end{array}$ \\
\hline \multicolumn{5}{|l|}{ Elopaino ennen poikimista } \\
\hline Kokeen alussa, kg & 694 & 692 & 20,8 & \\
\hline $1 \mathrm{vk}$ ennen poikimista, $\mathrm{kg}$ & 727 & 738 & 24,3 & \\
\hline Elopainon muutos vk 6-4 vk, kg/pv & $-0,1$ & 1,8 & 0,28 & $* * *$ \\
\hline Elopainon muutos vk 6-1 vk, $\mathrm{kg} / \mathrm{pv}$ & 1,1 & 1,3 & 0,18 & \\
\hline Vasikan syntymäpaino, kg & 47,0 & 40,7 & 2,25 & o \\
\hline \multicolumn{5}{|l|}{ Elopaino poikimisen jälkeen } \\
\hline $1-2$ pv poikimisen jälkeen, $\mathrm{kg}$ & 655 & 681 & 20,8 & \\
\hline 8 vk poikimisen jälkeen, $\mathrm{kg}$ & 632 & 650 & 18,9 & \\
\hline Elopainon muutos vk $0-8, \mathrm{~kg} / \mathrm{pv}$ & $-0,39$ & $-0,59$ & 0,17 & \\
\hline \multicolumn{5}{|l|}{ Kuntoluokka } \\
\hline Kokeen alussa & 3,7 & 3,6 & 0,10 & \\
\hline 5 pv ennen poikimista & 3,8 & 3,7 & 0,11 & \\
\hline Kokeen lopussa & 2,7 & 2,8 & 0,17 & \\
\hline
\end{tabular}

Ruokintaryhmien eläimet painoivat keskimäärin yhtä paljon ja olivat samassa lihavuuskunnossa kokeen alussa (Taulukko 2). V-ryhmän lehmien elopainon lisäys ummessaolokauden aikana oli keskimäärin $13 \mathrm{~kg}$ suurempi kuin R-ryhmän (ruokinta*aika $\mathrm{p}<0,001$ ). V-ryhmän painonlisäys kahden ensimmäisen viikon aikana oli $1,8 \mathrm{~kg} / \mathrm{pv}(\mathrm{p}<0,001)$, kun samaan aikaan R-ryhmä menetti painoaan keskimäärin $100 \mathrm{~g} / \mathrm{pv}$, mikä selittää ruokinnan ja ajan yhdysvaikutuksen. Lypsylehmien ruokintasuositusten (MTT, 2011) mukaan V-ryhmän lehmien suurempi energiansaanti olisi riittänyt noin 1,0 $\mathrm{kg} / \mathrm{pv}$ suurempaan elopainon lisäykseen R-ryhmään verrattuna. Ero ruokintaryhmien elopainon lisäyk- 
sessä oli siten odotettua pienempi. Kuntoluokissa poikimisen läheisyydessä ja elopainon sekä kuntoluokan muutoksissa poikimisen jälkeen ei ollut eroja.

R-ryhmän lehmien vasikat olivat painavampia kuin V-ryhmän ( $\mathrm{p}=0,08$; Taulukko 2). Olettaen, että vasikan painon lisäksi sikiökalvojen ja istukan painon osuus vasikan syntymäpainosta on $50 \%$ (Silva-del-Rio ym. 2010) ja toisaalta sikiön kasvun osuus elopainon lisäyksestä on keskimäärin 35-40 kg ummessolokauden aikana (NRC 2001, Douglas ym. 2006), ei näiden arvioiden mukaan R-ryhmän lehmien oma paino lisääntynyt ennen poikimista lainkaan. V-ryhmällä suurempi päivittäinen energiansaanti on saattanut kerryttää sisäelimiä ja vatsaonteloa ympäröivää rasvakudosta, sillä jo lievästi liikaa energiaa saavat lypsylehmät voivat lisätä viskeraalirasvan määrää ummessaolokaudella (Drackley 2011). Tätä muutosta ei pystytä kuntoluokituksen avulla havaitsemaan.

Taulukko 3. Plasman glukoosi-, NEFA- ja insuliinipitoisuudet

\begin{tabular}{cllll}
\hline & $\begin{array}{l}\text { Rajoitettu } \\
\text { ruokinta }\end{array}$ & $\begin{array}{l}\text { Vapaa } \\
\text { ruokinta }\end{array}$ & SEM & \multicolumn{2}{c}{$\begin{array}{c}\text { Merkitsevyys } \\
\text { Ruokinta }\end{array}$} & \\
\hline Rnokinta*aika \\
Glukoosi (mmol/l) & & & & \\
NEFA (mmol/l) & 4,4 & 4,3 & 0,11 & $*$ \\
Insuliini $(\mu \mathrm{IU} / \mathrm{ml})$ & 0,24 & 0,18 & 0,025 & 0 \\
Poikimisen jälkeen & 15,9 & 24,2 & 4,79 & 0 \\
Glukoosi $(\mathrm{mmol} / \mathrm{l})$ & 3,4 & 3,3 & 0,12 & \\
NEFA $(\mathrm{mmol} / \mathrm{l})$ & 0,49 & 0,46 & 0,063 & \\
Insuliini $(\mu \mathrm{IU} / \mathrm{ml})$ & 8,6 & 11,1 & 3,79 & \\
\hline
\end{tabular}

V-ryhmän lehmien veren NEFA-pitoisuus oli ennen poikimista pienempi kuin R-ryhmän lehmien ( $<<0,03$; Taulukko 3), mikä on seurausta suuremmasta energian saannista ja korkeammasta insuliinipitoisuudesta $(\mathrm{p}<0,09)$. R-ryhmän suurempi NEFA-pitoisuus viittaa siihen, että rajoitetusti ruokittujen lehmien alhaisempi insuliinipitoisuus vähentää lipolyysin inhibointia, jolloin rasvakudosmobilisaatio lisääntyy. Ruokinnan rajoittaminen ummessaolokaudella on nostanut aiemmissa tutkimuksissa NEFA-pitoisuutta ennen poikimista (Dann ym. 2006, Douglas ym. 2006). Glukoosipitoisuuksissa ei ollut eroa yhtäpitävästi aiempien tutkimusten kanssa (Holtenius ym. 2003, Douglas ym. 2006). Poikimisen jälkeen veriparametreissa ei ollut eroa.

Plasman NEFA-pitoisuus on hyvä rasvakudosmobilisaation indikaattori (Bell 1995). Rasvahappojen mobilisaation seurauksena maidon rasvapitoisuus nousee yleensä tuotoskauden alussa, jolloin huomattava osa maidon rasvahapoista on peräisin rasvakudoksesta. Poikimisen jälkeen plasman NEFA-pitoisuudessa tai maidon rasvapitoisuudessa ei ollut ryhmien välisiä eroja, mikä viittaa siihen, että runsas energiansaanti ummessaolokaudella ei aiheuttanut merkittäviä muutoksia rasvaaineenvaihdunnassa poikimisen jälkeen.

Taulukko 4. Glukoosirasituskoe ennen poikimista (-7 pv)

\begin{tabular}{|c|c|c|c|c|}
\hline & $\begin{array}{l}\text { Rajoitettu } \\
\text { ruokinta }\end{array}$ & $\begin{array}{l}\text { Vapaa } \\
\text { ruokinta }\end{array}$ & SEM & $\begin{array}{l}\text { Merkitsevyys } \\
\text { Ruokinta }\end{array}$ \\
\hline Glukoosi, perustaso (mmol/l) & 4,5 & 4,4 & 0,16 & \\
\hline Glukoosi, huippupitoisuus (mmol/l) & 15,8 & 16,9 & 0,60 & \\
\hline Glukoosi, poistumisnopeus ((\%/min) & 1,0 & 1,2 & 0,07 & \\
\hline Glukoosi, $\mathrm{AUC}_{180},(\mathrm{mmol} / 1 \times 180 \mathrm{~min})$ & 429 & 423 & 27,2 & \\
\hline Insuliini, perustaso $(\mu \mathrm{IU} / \mathrm{ml})$ & 37,5 & 43,4 & 5,7 & \\
\hline Insuliini, huippupitoisuus ( $\mu \mathrm{IU} / \mathrm{ml})$ & 300 & 366 & 74,4 & \\
\hline Insuliini, $\mathrm{AUC}_{180},(\mu \mathrm{IU} / \mathrm{ml}$ x $180 \mathrm{~min})$ & 11253 & 14987 & 3852,0 & \\
\hline NEFA, perustaso (mmol/l) & 0,26 & 0,17 & 0,03 & $*$ \\
\hline NEFA, alin pitoisuus (mmol/1) & 0,11 & 0,07 & 0,02 & \\
\hline NEFA, $\mathrm{AUC}_{60},(\mathrm{mmol} / 1 \times 60 \mathrm{~min})$ & $-3,5$ & $-2,4$ & 0,45 & $*$ \\
\hline
\end{tabular}


Taulukko 5. Glukoosirasituskoe poikimisen jälkeen $(+10 \mathrm{pv})$

\begin{tabular}{|c|c|c|c|c|}
\hline & $\begin{array}{l}\text { Rajoitettu } \\
\text { ruokinta }\end{array}$ & $\begin{array}{l}\text { Vapaa } \\
\text { ruokinta }\end{array}$ & SEM & $\begin{array}{l}\text { Merkitsevyys } \\
\text { Ruokinta }\end{array}$ \\
\hline Glukoosi, perustaso $(\mathrm{mmol} / \mathrm{l})$ & 3,2 & 3,1 & 0,23 & \\
\hline Glukoosi, huippupitoisuus (mmol/1) & 14,7 & 15,9 & 0,61 & \\
\hline Glukoosi, poistumisnopeus $((\% / \mathrm{min})$ & 1,9 & 2,0 & 0,15 & \\
\hline Glukoosi, $\mathrm{AUC}_{180},(\mathrm{mmol} / 1$ x $180 \mathrm{~min})$ & 299 & 310 & 18,0 & \\
\hline Insuliini, perustaso $(\mu \mathrm{IU} / \mathrm{ml})$ & 7,4 & 8,9 & 1,5 & \\
\hline Insuliini, huippupitoisuus ( $\mu \mathrm{IU} / \mathrm{ml})$ & 131 & 136 & 25,2 & \\
\hline Insuliini, $\mathrm{AUC}_{180},(\mu \mathrm{IU} / \mathrm{ml} \times 180 \mathrm{~min})$ & 3349 & 3857 & 1359,9 & \\
\hline NEFA, perustaso (mmol/l) & 0,49 & 0,56 & 0,06 & \\
\hline NEFA, alin pitoisuus (mmol/1) & 0,24 & 0,26 & 0,03 & \\
\hline $\mathrm{NEFA}, \mathrm{AUC}_{60},(\mathrm{mmol} / 1 \times 60 \mathrm{~min})$ & $-6,0$ & $-10,6$ & 1,65 & $*$ \\
\hline
\end{tabular}

Glukoosirasituskokeissa ennen poikimista (-7 d) ja poikimisen jälkeen $(+10 \mathrm{~d})$ ei ollut ryhmien välisiä eroja glukoosin perustasossa, huippupitoisuudessa, poistumisnopeudessa tai pitoisuus-aika käyrän alaisessa pinta-alassa (AUC; Taulukot 4 ja 5). Plasman NEFA-pitoisuuden perustaso oli Vryhmässä pienempi $(p=0,02)$ ennen poikimista. R-ryhmän NEFA:n AUC oli ennen poikimista itseisarvoltaan suurempi $(p=0,04)$, poikimisen jälkeen AUC oli suurempi V-ryhmässä $(p=0,02)$. Glukoosirasituskokeiden aikana havaitut NEFA-muutokset saattavat viitata siihen, että rajoitetusti ruokittujen lehmien rasvakudos oli herkempi insuliinin vaikutukselle ennen poikimista, kun taas poikimisen jälkeen vapaasti ruokittujen lehmien insuliiniherkkyys oli rajoitetusti ruokittuja parempi. Märehtijän rasvakudos on muita kudoksia herkempi insuliinin vaikutukselle (Petterson ym. 1993, 1994), mikä voi selittää sen, että insuliiniherkkyyden muutoksia kuvaavien glukoosiparametrien kohdalla ei havaittu ruokintaryhmien välisiä eroja.

\section{Johtopäätökset}

Ummessaolokauden runsas energiansaanti ei aiheuttanut merkittäviä muutoksia lehmien aineenvaihdunnan säätelyssä ja kudosmobilisaatiossa tai elopainossa ja kuntoluokan muutoksissa poikimisen läheisyydessä rajoitettuun ruokintaan verrattuna. Vapaa ruokinta ummessaolokauden alussa nosti veren plasman insuliinipitoisuutta ja rajoitettu ruokinta puolestaan suurensi veren NEFA-pitoisuutta ennen poikimista. Ummessaoloaikana rajoitetusti ruokittujen lehmien maitotuotos oli suurempi laktaatiokauden alussa.

\section{Kirjallisuus}

Agenäs, S., Burstedt, E. \& Holtenius, K. 2003. Effects of feeding intensity during the dry period. 1. Feed intake, body weight, and milk production. Journal of Dairy Science. 86:870-882.

Bell, A. W. 1995. Regulation of organic nutrient metabolism during transition from late pregnancy to early lactation. Journal of Animal Science 73:2804-2819.

Boden, G. 2011. Obesity, insulin resistance and free fatty acids. Current Opinion in Endocrinology, Diabetes and Obesity 18:139-143.

Bossaert, P., Leroy, J. L. M. R., Campeneere, S. D., Vliegher, S. D. \& Opsomer, G. 2009. Interrelations between glucose-induced insulin response, metabolic indicators, and time of first ovulation in high-yielding dairy cows. Journal of Dairy Science 91:3363-3371.

Dann, H.M., Litherland, N.B., Underwood, J.P., Bionaz, M., D’Angelo, A., McFadden, J.W. \& Drackley, J.K. 2006. Diets during far-off and close-up dry periods affect periparturient metabolism and lactation in multiparous cows. Journal of Dairy Science 89:3563-3577.

Douglas, G.N., Overton, T.R., Bateman, H.G., Dann, H.M. \& Drackley, J.K. 2006. Prepartal plane of nutrition, regardless of dietary energy source, affects periparturient metabolism and dry matter intake. Journal of Dairy Science 89: 2141-2157.

Drackley, J. 2011. Optimizing production of the dairy cow: Nutrition and management during late pregnancy. Journal of Animal Science 89:(E-Suppl. 1.)691(abstr. 672).

Grummer, R.R., Mashek, D.G. \& Hayirli, A. 2004. Dry matter intake and energy balance in the transition period. Veterinary Clinics of North America: Food Animal Practice 20: 447-470. 
Holtenius K., Agenäs, S., Delavaud, C. \& Chilliard, Y. 2003. Effects of feeding intensity during the dry period. 2. Metabolic and hormonal responses. Journal of Dairy Science 86: 883-891.

Kokkonen, T., Taponen, J., Anttila, T., Syrjälä-Qvist, L., Delavaud, C., Chilliard, Y., Tuori, M. \& Tesfa, A.T. 2005. Effect of body fatness and glucogenic supplement on lipid and protein mobilization and plasma leptin in dairy cows. Journal of Dairy Science 88: 1127-1141.

Kokkonen, T., Tesfa, A.T., Tuori, M. \& Syrjälä-Qvist, L. 2004. Concentrate feeding strategy of dairy cows during transition period. Livestock Production Science 86: 239-251.

Law, R.A., Young, F.J., Patterson, D.C., Kilpatrick, D.J., Wylie, A.R.G., Ingvartsen, K.L., Hameleers, A., McCoy, M.A., Mayne, C.S. \& Ferris, C.P. 2011. Effect of precalving and postcalving dietary energy level on performance and blood metabolite concentrations of dairy cows throughout lactation. Journal of Dairy Science 94:808-823.

Loor, J.J., Dann, H.M., Janovick -Guretzky, N.A., Everts, R.E., Oliveira, R., Green, C.A., Litherland, N.B.,Rodriguez-Zas, S.L., Lewin H.A. \& Drackley, J.K. 2006. Plane of nutrition prepartum alters hepatic gene expression and function in dairy cows as assessed by longitudinal transcript and metabolic profiling. Physiological Genomics 27: 29-41.

Murondoti, A., Jorritsma, R., Beynen, A. C.,Wensing, T. \& Geelen, M. J. H. 2004. Unrestricted feed intake during the dry period impairs the postpartum oxidation and synthesis of fatty acids in the liver of dairy cows. Journal of Dairy Science 87:672-679.

NRC. 2001. Nutrient Requirements of Dairy Cattle. National Research Council. 7th rev. ed. National Academy Press, Washington, DC.

MTT 2011. Rehutaulukot ja ruokintasuositukset. Maa- ja elintarviketalouden tutkimuskeskus. Saatavissa internetissä: https://portal.mtt.fi/portal/page/portal/Rehutaulukot.

Patton, J., Murphy, J. J., O'Mara, F. P. \& Butler, S. T. 2009. Responses of North American and New Zealand strains of Holstein-Friesian dairy cattle to homeostatic challenges during early and mid-lactation. Animal 3: 251-260.

Petterson, J. A., Dunshea, F. R., Ehrhardt, R. A. \& Bell, A.W. 1993. Pregnancy and undernutrition alter glucose metabolic responses to insulin in sheep. Journal of Nutrition 123:1286-1295.

Petterson, J. A., Dunshea, F. R., Ehrhardt, R. A. \& Bell, A.W. 1994. Pregnancy but not moderate undernutrition attenuates insulin suppression of fat mobilization in sheep. Journal of Nutrition 124:2431-2437

Pires, J. A. A., Pescara, J. B., Brickner, A. E., Silva del Rio, N., Cunha, A. P. \& Grummer, R.R.. 2008. Effects of abomasal infusion of linseed oil on responses to glucose and insulin in Holstein cows. Journal of Dairy Science 91:1378-1390.

Rukkwamsuk, T., Wensing, T. \& Geelen, M.J.H. 1999. Effect of fatty liver on hepatic gluconeogenesis in periparturient dairy cows. Journal of Dairy Science 82: 500-505.

Salin, S., Kokkonen, T., Kuitunen, M., Taponen, J., Elo, K. \& Vanhatalo, A. 2010. Juoksutusmahaan infusoidun rasvalisän vaikutus ummessaolevien lehmien insuliiniresistenssin kehittymiseen. Julkaisussa: Maataloustieteen Päivät 2010 [verkkojulkaisu]. Suomen Maataloustieteellisen Seuran julkaisuja no 26. Toim. Anneli Hopponen. Saatavilla Internetissä: http://www.smts.fi

Silva-del-Rio, N., Fricke, P. M. \& Grummer, R. R. 2010. Effects of twin pregnancy and dry period feeding strategy on milkproduction, energy balance, and metabolic profiles in dairy cows. Journal of Animal Science 88:1048-1060.

Winkelman, L.A., Elsasser, T.H. \& Reynolds, C.K. 2008. Limit-Feeding a high-energy diet to meet energy requirements in the dry period alters plasma metabolite concentrations but does not affect intake or milk production in early lactation. Journal of Dairy Science 91:1067-1079. 